anthropology \& materialism

\section{Anthropology \& Materialism}

A Journal of Social Research

Special Issue | I | 2017

Discontinuous Infinities

\title{
The World of Striving
}

Walter Benjamin's 'Notes to a Study on the Category of Justice'

\section{Andrew Benjamin}

\section{(2) OpenEdition}

Journals

Electronic version

URL: http://journals.openedition.org/am/823

DOI: $10.4000 / a m .823$

ISSN: 2364-0480

Publisher:

CETCOPRA, CRASSH - Center for Research in the Arts Social Sciences and Humanities, Fakultät Gestaltung - Universität der Künste Berlin

Electronic reference

Andrew Benjamin, «The World of Striving », Anthropology \& Materialism [Online], Special Issue | | | 2017,

Online since 06 February 2018, connection on 03 May 2019. URL : http://journals.openedition.org/ am/823 ; DOI : 10.4000/am.823

This text was automatically generated on 3 May 2019.

Tous droits réservés 


\title{
The World of Striving
}

\author{
Walter Benjamin's 'Notes to a Study on the Category of Justice'
}

\author{
Andrew Benjamin
}

\author{
"Methode ist Umweg. Darstellung als Umweg - das \\ ist denn der methodische Charakter des Traktats." \\ Walter Benjamin \\ "V'shaf'tu et ha'am mishpat tzedek". [They shall \\ judge the people with righteous judgment.] \\ Sefer Devarim, 16:18
}

\section{Kant: Justice in the World}

1 That Walter Benjamin's short text - 'Notes to a Study on the Category of Justice' - is an engagement with Kant is clear. ${ }^{1}$ The language deployed within it, it might be argued, is for the most part derived from Kant (though the status of that derivation is yet to be clarified). And if philosophy, in terms of presentation, is constrained to think within its own self-presentation in language (as language) then this short text is an already present engagement with Kant. Interpretations by Eric Jacobson and Peter Fenves, for example, divide in terms of their identification of the place of Kant. ${ }^{2}$ For Fenves, at least as a beginning, his sustained and systematic engagement with this text seeks to locate it within an analysis of Kant's Doctrine of Virtue (1797). The project here, while conceding the centrality of 'virtue' is slightly different. Kant endures. Nonetheless, it is another Kant, perhaps a Kant that delimits an opening beyond Kant, which would be the point where Kant's own structure of thought would have slipped beyond Kant's own hold. Precisely because the word (or term) 'world' [Welt] occurs in Benjamin's text in a way that recalls Kant, the argument to be advanced here is that what is at stake in the encounter between Benjamin and Kant is to be found both in how the 'world' is thought and then in the differing sets of consequences to which their respective modes of thought gives rise. While there might be points of terminological association between Kant and Benjamin, the relation between them emerges from the way those associations are positioned by the radically different philosophical claims of which they are the expression. 
2 As a consequence, rather than start with the evocation of virtue as though it were an end in itself, there is another way to begin. It goes without saying that Benjamin's text is a sustained encounter with 'justice'. And the question of justice pertains both to the presence of justice in the world and then with the nature of that presence and thus the quality of the world that is envisaged; i.e. the complexity inherent in any evocation of the world of justice, once the world is no longer accepted as merely given. To make the task more exact, what has to be addressed is the following: what counts as worldliness once the question of the world emerges from within the suspension of both empiricism and the stubborn insistence of naturalism? Once taken together, the world and then justice as occurring within the world, the term 'world' now as a concept whose force remains to be determined, determined nonetheless from within the purview of empiricism's suspension, means that the project to be pursued concerns how the delineation of worldliness is to be made more exact. An intimation of how to proceed is already clear from Benjamin's text. Benjamin writes that, "Justice appears not to be based upon the good will of the subject but forms the state of the world [einen Zustand der Welt]." 3 What is staged here is a repositioning of the subject/world relation, and therefore a transformation of how the contents of that relation are themselves to be conceived. There will be a repositioning. The subject as worldly, as having become worldly, not only follows from this undoing of the subject's centrality, it simultaneously allows for the world's ineliminability. (A quality that obtains beyond forms of presentation that would have been linked to the merely posited.) More significantly, it is to start with a different philosophical anthropology, and thus with another subject, one which posses a different sense of worldliness. Hence there is a different demand: what is the subject and what is its world when justice pertains not to a subject's will but to the world itself? (Possible worlds become conditions of the world - this world - and not a subject's projective will.) Inherent within any answer is the recognition that the subject is only ever an effect of the world; an after-effect of the world. Posed within the question of justice as worldly, there within its fabric as a form of interrogation, is the proposition of the always possible nonpresence of justice in the world other than as a potentiality. As a result there is an ever present even if unstated problem at work here, which concerns how justice's actuality is to be understood. The contention of the overall argument to be presented here is that the proposition pertaining to justice's yet-to-be quality, and the subsequent issue of how to think justice's actualization, are at the heart of Benjamin's text.

3 Part of the argument to be advanced in what follows concerns showing in what way a necessary split or severance within the conception of the world is equally present within the way justice is thought. The positing of the necessary worldliness of justice, in which justice is a quality of this world, thus not the world to come, thus as occurring 'not in heaven', demands a divide between the actuality of justice's claims, which can be equated with forms of normativity in the first instance, and then, in the second, with the possibility of justice as that which awaits actualization. ${ }^{4}$ The move from one to the other demands both a rethinking of worldliness and thus of justice as worldly. What needs to be worked out is another conception of justice, which, while worldly, insofar as its force pertains to the world, is a conception of justice that has to be thought in terms of its sustained differentiation from normativity. The latter, that which would emerge from such a differentiation, would be a conception of justice that attends, and thus has to be thought in terms of, immanence..$^{5}$ Moreover, it would be in terms of justice as a continually immanent possibility that a critique of the identification of justice with 
normativity could then be developed. Immanence here can be described as having the quality of the Kantian 'unconditioned'. As such it would then be the unconditioned for any conditioned, to deploy a formulation that is close to Kant's thinking of the unconditioned. The force of the term 'immanence' can be found in the nature of its link to the practical, and thus to worldliness. In addition, it would be its necessary separation from the domain of actuality that allows for an opening, and thus of what will emerge as the inscription of a spacing which can be rethought in terms of critique. Within this specific setting actuality pertains to the necessity of actualization within which there would have been an axiomatic identification of normativity with justice. In such a context normativity is the set of constraints in which moral and legal concerns become coincident with justice. It would be a sense of coincidence that was forced, and which demanded the continuity of its being reinforced. The undoing of this coincidence involves a reconfiguration of the way the concept of the world and the worldliness of its contents are present. The world, as a consequence of that undoing, would come to be incorporated into another philosophical formulation.

Once worldliness is taken as the point of orientation, the formulation from Benjamin's text with which to begin is the following:

Justice is the striving to make the world into the highest good. [Gerechtigkeit ist das Streben, die Welt zum höchsten Gut zu machen.] $]^{6}$

5 Precisely because of an initial affinity that allows for an ensuing severance, the severance of Kant and Benjamin, of the many elements that demand elaboration, a start will be made with a term that, while it appears and plays a fundamental role in Benjamin's formulation of justice, is also central to Kant's wider philosophical project. A term which, while it suggests an affinity, the affinity between Kant and Benjamin, it will be in the breakdown of that affinity that a relation, which had yielded a fluidity of connection, and which - in the end - will have become a relation of non-relation, is then the one that allows for the particularity of Benjamin's text, and thus its philosophical project to emerge. It emerges, of course, in its differentiation from Kant. The term is 'striving'. The line noted above from Benjamin's text has, at the outset, an affiliation to a position announced in the Critique of Practical Reason (1788). The affiliation is complex. There is the already noted possible connection and a severance. The position which allows for the intimation of an affinity is presented by Kant in the following terms:

What belongs to duty here is only the striving to produce and promote the highest good in the world, the possibility of which can therefore be postulated, while our reason finds this thinkable only on the presupposition of a supreme intelligence. ${ }^{\text {? }}$

6 What has to be noted from the start is the distinction between Benjamin's formulation - ' to make the world into the highest good' - and Kant's, which pertains to 'the highest good in the world'. It will be essential to return to this distinction, and thus to these divergent conceptions of world, in order to discern what is at stake in their difference. The question is clear: how is the difference between these two presentations of the world to be thought?

7 'Striving' is a term that continues to appear in Kant's writings. In The Vienna Logic (c. 1780) "wisdom", which is the "doctrine" of "true philosophy", is described as that which "must be the highest good for our striving". ${ }^{8}$ In The Critique of Practical Reason the 'law' is described as having an enjoined lived relation within which that 'law' is present as "the constant though unattainable goal of (his) striving". ${ }^{9}$ In the The Metaphysics of Morals 
(1797), Kant's formulation once again brings an important division into play within which 'striving' forms a central component. Kant writes:

It is readily seen that friendship is only an idea (though a practically necessary one) and unattainable in practice, although striving for friendship (as a maximum of a good disposition toward each other) is a duty set by reason, and no ordinary duty but an honorable one. ${ }^{10}$

Formally, what is fundamental here is the equation of the 'idea' with the 'unattainable'. The 'idea' cannot be possessed. It is immanent. And as a result it cannot be the object of a 'having'. (Here of course is a genuine point of affinity with Benjamin in terms of the latter's critique of what he identifies in the "Notes to a Study on the Category of Justice" as the attribution of a 'possessive character' to the 'good'). The question that continues to return with Kant, however, concerns the nature of this striving and its delimitation by the 'unattainable'. In order to respond, the point of departure involves noting that 'striving' is present within the world (reciprocally, of course, the world is the place of striving). What this means is that that the real question to be addressed concerns what striving opens, or rather, perhaps more accurately, what it demands is a response to the question of what delimits the specificity of the world of Kantian striving. It is essential to stay with Kant in order that the nature of the relation between Benjamin's reference to striving and Kant's own references can emerge. As will become clear what is at stake is that to which allusion has already been made, namely two radically different ways the 'world' is construed.

9 At the outset, what complicates Kant's conception of striving is that, for Kant, 'striving', as it takes place within the domain of duty, is only intelligible in relation to what he presents as 'the presupposition of a supreme intelligence'. Such a formulation is, of course, similar to the one in which 'friendship' is present as an 'idea'. There is a structural similarity. However, it is essential to proceed cautiously here since what matters is not the presence of a 'supreme intelligence', as though all that is being evoked is the epistemological register of a deity, but of that which is present in its irreducibility to the actual. (While this is of course the essence of a political theology, further clarification is still necessary.) To invert the position presented by Kant elsewhere in the Critique of Practical Reason, human virtue is not "a mere phantom", hence neither the law nor the unconditioned are objects of superstition, and, as a result, to cite Kant, "striving toward it" cannot "be deprecated as vain affectation and delusive self-conceit". ${ }^{11}$ Note, however, that virtue even though it is not a 'phantom' is still not actual. It is an insistent potentiality rather than an assumed necessity. At every moment virtue (and duty) endure as possibilities. The possibility of actuality is equally the possibility that there will not be an actualization. Potentiality and im-potentiality are always coterminous in their difference (this form of co-presence repeats the insight advanced by Aristotle in the Metaphysics, namely that potentiality - as a generality - is always co-present with a corresponding im-potentiality. ${ }^{12}$ When taken together they comprise the intersection of contingency, finitude and freedom. This intersection delimits how modes of actuality are to be understood. In this context, it refers to the actualization of a potentiality, which starts with the assumption of the non-necessity of actualization.

10 Given the distinction between the potential and the actual and their ensuing relation, a relation in which the contingency of connection is central, the necessity that pertains to virtue or duty is then the non-necessity of their actualization. It is this non-necessity that locates and demands striving. To which it should be added that this non-necessity yields 
the space that both sanctions and envisages striving. In other words, what such a setup sustains is a spacing at the center of the relation that the potential and the actual constructs; a spacing that constitutes and sustains that relation. (The argument will be that it is a spacing whose transformed retention forms a fundamental element that allows for the move from Kant to Benjamin.) In the Kantian context what this setup entails is, in sum, that virtue is yet-to-be actualized, and thus it is this yet-to-be quality which occurs in the world, in the precise sense that it is yet-to-be actualized as such, even though striving towards it is an activity that is inherently worldly. Striving is linked therefore to the possible becoming worldly of virtue. And it should be noted that the world figures insofar as it is retained as the place in which virtue attains (or not) actuality.

There is however always a limit and thus the further delimiting of a space. The following formulation in The Critique of the Power of Judgment provides a clear instance of that limit:

The feeling of the sublime is thus a feeling of displeasure from the inadequacy of the imagination in the aesthetic estimation of magnitude for the estimation by means of reason, and a pleasure that is thereby aroused at the same time from the correspondence of this very judgment of the inadequacy of the greatest sensible faculty in comparison with ideas of reason, insofar as striving for them is nevertheless a law for us [sofern die Bestrebung zu denselben doch für uns Gesetz ist]. That is, it is a law (of reason) for us and part of our vocation to estimate everything great that nature contains as an object of the senses for us as small in comparison with ideas of reason; and whatever arouses the feeling of this supersensible vocation in us [dieser übersinnlichen Bestimmung in uns] is in agreement with that law. 13

To continue the adumbration of 'striving' as integral to understanding the way the 'world' is thought in Kant's larger philosophical project, it should be underscored that what occurs in the above is a description of the subject who strives to live in relation to the 'ideas of reason' and who, even though the subject is let down by the 'inadequacy of the imagination', nonetheless still recognizes that at the heart of that relation there is a necessity to strive. A space appears. Striving cannot be differentiated from the law even though that striving will, in this instance, be linked to impossibility or unattainability. Subjects, as those who live in relation to the law, strive. Striving occasioned by the specificity of the human orientation, defined by Kant in terms of our 'vocation' [ Bestimmung] is that which allows for the attempt, albeit the continual attempt, to live a life that is lived together with the law. The relation between potentiality and actuality, and thus the dynamic of striving, has as a result a doubled presence, always divided between the potential and the actual, the necessity for a form of apartness. Again there is the inscribed presence of what continues to be maintained as an effective spacing. The spacing is effective insofar as it allows for judgment and thus the actuality of the particular.

While the term 'striving' has a life beyond Kant, since it also appears in Benjamin's text, at this stage it needs to be understood within the setting that Kant creates. Moreover, it is this understanding that allows for the particularity of Kant's own position to emerge. As has been noted, there is a condition that defines and delimits Kant's overall engagement with the dynamic of striving. As has been indicated, it constitutes and depends upon a spacing. This further condition pertains to the world. Specifically it pertains to Kant's conception of the world. It is simply that, even though striving brings about a transformation in the subject, which itself can be understood as the actualization of a potentiality, as a result of arousing 'the feeling of this supersensible vocation in us', that 
transformation is itself orientated by the promotion of 'the highest good in the world'. The project or task that arises in the context of Kant's overall argumentation does not pertain to the actualization of the highest good as though that end set the measure. Rather, its necessary non-actualization allows duty to be delimited in terms of striving. Striving becomes a locus of possibility. The important consequence is that striving in the world repeats the world. It is repeated as the place of striving. As such the world remains the same. The world endures as the simply given. This is the precondition for defining striving in terms of actions that aim to promote 'the highest good in the world'. The world, as the place of striving, endures. It continues as unchanged by this promotion. The retained reiteration of the world as the unchanging place of striving is the empiricism at the heart of Kant's conception of 'world'.

\section{Benjamin: The Just World.}

Turning to Benjamin's text and thus to the conception of striving within it, is not just to turn from one text to another. More emphatically, it is to turn to another possibility for thinking the world. The beginning of Benjamin's texts has a specific concern. He writes:

Every good, limited by structures of time and space, has a possessive character trait that is an expression of its ability to pass away. [Jedem Gute, als in der Zeit- und Raumordnung eingeschränktem, kommt Besitzcharakter als Ausdruck seiner Vergänglichkeit zu. $]^{14}$

15 There are difficulties with this formulation that are clear from the start. What is at stake is a form of oscillation between the 'good' understood as a moral term and another sense that equates goods and thus the good with that which can be possessed (the latter in an almost material sense, thus almost literally as goods). In regards to the latter good, as a commodity it is articulated within a logic of needs and satisfaction, and thus a logic of utility. Indeed, it is possible to go further and argue that Benjamin is moving between these two different though related senses of the good (and of goods). Moreover, given this oscillation what is then at stake is the evaluation of the moral (or the ethical) within terms set by a sense of the good that is possessed, acquired, perhaps even bought. This would be the good as located within the logic of utility already noted. What has to be undone is this specific twofold sense of goods/good. Within the setup to be undone not only is there utility, there is a necessary dependence within this position on the primacy of a subject. One logic incorporates the other. Possession and the primacy of the subject's will are present as inter-articulated. An undoing of one therefore becomes the undoing of the other.

16 A good that is a finite entity, hence one which is delimited spatially and temporally and attributed the quality of being possessed - i.e. a good as possessable, and, in being possessed, knowable, since knowing is a possessing - for Benjamin cannot 'lead to justice' [zur Gerechtigkeit führen]. ${ }^{15}$ Benjamin's text begins with this claim. Once any good (i.e. any conception of the good/goods) is thought as that which can be possessed, and therefore would be an object of a form of having, is as a result 'always unjust' [immer ungerecht]. ${ }^{16}$ Despite the link between knowing and possessing this other good, the other possibility for the good/goods, the one that undoes the interconnection between good and possession, cannot be approached as if it were unknowable. It is neither ineffable nor mystical. The significant point is that it cannot be possessed. The good to be present must be a form of presentation. The strategy has to be changed. There needs to be another structure of 
thought. The move is clear. Once it can be argued that the good cannot be possessed then it takes on the quality of an 'idea'. This limit, and thus that which has to be overcome, is the attribution to the good of what Benjamin calls 'a possessive character' [Besitzcharakter ].

The term Besitzcharakter is not generally prevalent in Benjamin's writings. However, it does occur in the opening of The Origin of German Tragic Drama. It figures in what might be more generally understood as a stand against knowledge. Benjamin, in a passage that can be located just after the celebrated identification of method with 'digression' [Umweg], writes that:

If presentation is to stake its claim as the genuine methodology of the philosophical treatise, [Wenn Darstellung als eigentliche Methode des philosophischen Traktates sich behaupten will] then it must be the presentation of ideas [so muß sie Darstellung der Ideen sein.] Truth, bodied forth in the dance of presented ideas [der dargestellten Ideen], resists being projected, by whatever means into the realm of knowledge. Knowledge is a having. [Erkenntnis ist ein Haben.] Its very object is determined by the fact that it may be taken possession of - even if in a transcendental sense - in the consciousness. The quality of possession remains. [Ihm bleibt der Besitzcharakter.] For the thing possessed, presentation is secondary [Diesem Besitztum ist Darstellung sekundär]; it does not have prior existence as something presenting itself. But the opposite holds good for truth. For knowledge method is a way [ein Weg] of acquiring its object - even by creating it in the consciousness; for truth it is self-presentation and is therefore immanent in it as form. ${ }^{17}$

The 'good' like the 'idea' must show itself. The link to Plato becomes clear. Once it can be argued that the 'good' is not there to be possessed, and were that to be attempted it would then be dissipated and lost, a different, if nonetheless still direct task is at hand. In this regard Benjamin is precise. The 'good' must be able to 'sublate' [aufhebt] what has been attributed to it, namely 'its possessive character' [seinen Besitzcharakter]. Knowledge is displaced for the precise reason that it is 'a having' [ein Haben]. What needs to be overcome is the identification of a good, in both senses of the term good, with an individual need (thus the need of an individual). There is another way. What is counterposed to that which centers on the individual, in which 'the good' becomes no more than a good, and which, furthermore, in being possessed (thus known), is then lost, contains a specific conception of abstraction. The formulation while complex is nonetheless still exact. He writes:

There is, namely, the entirely abstract claim of the subject to every good in principle, a claim that is not based on needs but rather on justice [ein Anspruch, der keineswegs auf Bedürfnisse, sondern auf Gerechtigkeit sich zurückführt] and whose last inclination will not possibly concern the right to possession [ein Besitzrecht] of the individual but a right to goods of the good [sondern auf ein Guts-Recht des Gutes geht]. 18

Here, once again, is the movement beyond the individual. It is as though there is a preceding right, and yet were that to be the case it would be a right that fell beyond the hold of possession, and as such could not be defined in the terms set either by different modalities of possession or as delimited by a subject's will. It would become a right whose position is similar to the setting of the idea, i.e. an enduring immanence, thus a pervading presence. What is at work within the repositioning is the presence of right that exists on the level of the idea and thus a right, the presentation of which becomes the issue. Presentation cannot be thought in terms that are purely re-presentational. Again for Benjamin this is the prolongation of the idea. What then of its presentation? Questions clearly proliferate. A lot more needs to be added here concerning what would amount to a 
counter-measure to a setup that is constructed by the individual, the individual's possession of the good and thus, and of fundamental importance, the construction of the good as that which can be possessed. And, if only to labour the point, it is essential to note the inherent reciprocity between all these elements.

At it most straightforward what is at work here is the move away from the individual and thus a repositioning of the 'good' beyond an economy structured by possession. (The 'good' will re-emerge as the analysis unfolds as the 'propertyless' [besitzlos].) ${ }^{19}$ The full force of attributing centrality to possession is that, to the extent that it continues, it would have been governed by the subject. Present therefore within such a setting is a structure of governance in which the individual is sovereign, a structure the maintenance of which may give rise to violence precisely because of the impossibility of a selfsustaining form of continuity. Governance would be constrained to maintain a form of continuity whose prolongation would become increasingly tenuous. The inscription of insecurity and violence occasions the entry of 'justice'. This is not just a shift in register. With that entry the 'good' occurs again. The 'good' now is there, not as that which is to be possessed or 'had', but as that which emerges with the possible prevailing of justice. And it should be added that it is this possibility, and, therefore, justice as a potentiality, that underscores what is essential here. Hence, to the extent the individual is located within an economy of possession, the world is maintained. Maintaining it however will give rise to repeated acts of violence. Violence is the province of individuals and violence individualizes. As Hannah Arendt argues, this is the nature of the distinction between violence and power. ${ }^{20}$ Benjamin can be read, after the event, as alluding to such a position when he claims that:

Justice is the power of virtue and virtue of power'. [Gerechtigkeit ist die Macht der Tugend und die Tugend der Macht.] $]^{21}$

Power, not violence, is an essential element of justice. What is equally the case is that the undoing of that setup, the counter-measure as effective, necessitates another world. This is not the positioning of a utopia. That other world is one that is to be made. Following the argument of the "The Destructive Character", a text published fifteen years after the writing of the short text on justice, it is a world for which there cannot be an accompanying image. ${ }^{22}$ The prevailing of justice however is only ever a possibility and thus is only ever present as a potentiality to be actualized. The next lines of Benjamin's text make this abundantly clear. Within them, not only does Benjamin's sense of striving make its appearance, more importantly striving becomes a project of world making. It is the reconfigured connection between justice and world-making that makes the former "a new ethical category" [eine neue ethische Kategorie]. ${ }^{23}$ The full formulation is the following:

Justice is the striving to turn the world into the highest good. [Gerechtigkeit ist das Streben, die Welt zum höchsten Gut zu machen]. These thoughts lead to the supposition that justice is not a virtue like other virtues (humility, neighborly love, loyalty, courage), but rather constitutes a new ethical category [eine neue ethische Kategorie], one that should probably no longer be called a category of virtue but a category of virtue in relationship to other categories. Justice appears not to be based upon the good will of the subject but forms the state of the world. [Gerechtigkeit scheint sich nicht auf den guten Willen des Subjekts zu beziehen, sondern macht einen Zustand der Welt aus] ... While virtue can be demanded, justice, in the end, can only be the state of the world or the state of God. In God all virtues take the form of justice [Tugend kann gefordert werden, Gerechtigkeit letzten Endes nur sein, als Zustand der Welt oder als Zustand Gottes. In Gott haben alle Tugenden die Form der Gerechtigkeit ${ }^{24}$ 
While this passage will always have demanded a more detailed elaboration than can be provided here, what will be noted in this instance is the claim that defines what is essential to a political theology, namely the assertion that: 'justice, in the end, can only be the state of the world or the state of God.' If there is a stand that needs to be made in regards to the way 'virtue' emerges, then it has to be taken in relation to God. This position is advanced on the premise that justice is not to be defined in relation to a subject's will. Theology appears. God comes in the wake of the subject. Consistent with what has already been argued, it is essential to note that the term 'God' no longer names an entity within any form of epistemology. On the contrary. What God names is a conception of justice where the latter is imbued with power. Hence in God 'all virtues take the form of justice'. As a result virtue is stripped of its incorporation into a logic of possession; a logic defined by the interplay of having, knowing and representing. It will have finally become 'propertyless' [besitzlos]. The question that presses on this setup, and it is a question that allows for an affinity with Kant, even though it is an affinity that, at the same time, can be brought into question, concerns the possible actualization of justice as a state of the world. The premise is of course that the state of the world is such that it is not just. It is not that subjects do not act justly and ought so to do. The subject/world relation within such a setting is misconstrued. Subjects are effects of a world that is not just. Hence the critique of having and possession, while it may lead to a shift in a subject's orientation, is not delimited by that change. To recall what has already been suggested, it involves a reconfiguration of the subject/world relation, and thus the emergence of another philosophical anthropology. Justice endures as a possibility whose actualization is the same - structurally the same - as God's actualization in the world. This is the messianic impulse. (Its force shown 'weakly' within any one singular just act.) Once thought within the structure of a political theology, it is the refusal of religion. Religion's focus maintains the world, allowing only for goods to be possessed (or not) by individuals. What is at work here is fundamentally different, namely that potentiality for the world to be just and not to be merely the place of apparently just acts.

\section{The World's Othering.}

The two positions and conceptions of the world are now clear. For Kant there is the striving to produce what he has identified as 'the highest good in the world'. Within such a setting, 'striving' is there as that which delimits and enacts what he describes as 'the observance of duty'. Being dutiful is located in the worldly process of striving. To which it has to be added that the contingency of ethical action cannot be separated from the necessity that prompts action. What this entails is not just that the unconditioned is effective insofar as it is itself the condition for acting; equally it is part of the world. It endures as an immanent presence whose force is located in the necessity of its nonactualizability. The counter involves the introduction of another conception of the relationship between action and world, and thus the inflection of the spacing that constitutes the relation between immanence and actuality in Kant. (And note that it is an inflecting and precisely not an abandoning.) The counter-measure located in Benjamin's text is to make the world 'the highest good'. Hence there is a demand for the transformation of the world. Again, there is the assumption that the world is transformable. If there is a further reference to be made that underscores this possibility then it is to Thesis XI of Marx's "Theses on Feuerbach". Marx wrote that: "The 
philosophers have only interpreted the world, in various ways; the point is to change it." ${ }^{25}$ It is the last part of the thesis, 'the point is to change it' [es kömmt drauf an, sie zu verändern], which is significant since what it affirms is the possibility that the world can be other than it is. And not just that there may be other activities occurring within it, where their occurrence perpetuates the world. The possible othering of the world is the world as transformable. The world loses, therefore, the empiricist quality that it had within Kant's argumentation. Nonetheless, this still assumes Kant's starting point, namely the presence of justice defined in terms of its yet-to-be actualized quality. The constitutive spacing endures. It endures as the condition allowing for the unconditioned to function as a regulative possibility. And yet what it also holds open is the possibility of the world's transformation. The further point is that the world's transformability is that which allows for the unconditioned to function as the ground of critique.

24 To move back to the question of critique, it is now possible to identify two modes. They will be outlined in lieu of a more programmatic conclusion. The first conception of critique has to assume the necessary non-actualization of any modality of a justice to come. Kant's sense of the 'unconditioned', Derrida's 'unconditional hospitality', or 'unconditional forgiveness', etc., provide a way of understanding what is at stake within this conception of critique. ${ }^{26} \mathrm{Hence}$, in always remaining there as the to come, the to come is absorbed into the structure of the everyday. The absorption is, however, specific. It creates a world that holds the to come in place but refuses, at the same time, a conception of the world as subject to its own self-overcoming. Here that holds potentiality and actuality apart, a spacing endures and yet it is given an ineliminable positivity.

The second sense of critique, while assuming the non-actualization of the unconditioned/ idea (or that which has a similar structure) as the setup that allows for critique, inscribes a fundamental difference within it. What remains open, open as opposed to circumvented from the start, is the possibility of the world's transformation. Hence while critique is still grounded - as had been suggested - in the non-actualization of the unconditioned within which the possibility of judgment and critique stands in a similar relation to the unconditioned (or the 'unconditional'), nonetheless what such states of affairs have to leave open, or rather sustain, is a conception of the world that is no longer retained as the same. (Again this is retention as repetition.) Here is the limit of Kant's conception of the world. The move therefore is from a Kantian conception of history, one which is articulated within the project of gradual enlightenment, to what amounts to the history of another world.

Benjamin addresses the intricacy of historical time in this text in a way that is consistent with the approach he takes to that question in subsequent texts. He writes that:

The problem of historical time is already presented in the original form of the historical counting of time. Years are countable but in contrast to most countable things, cannot be numbered [nicht numerierbar]. ${ }^{27}$

Time is now that which, while bearing dates and thus being countable, cannot be understood in the terms set by the simple passing of time. The truth of historical time resists both calculation and numbering. What is present, therefore, the world that demands this other conception of historical time, is a world bounded by its own inscription, and thus reinscription, of the messianic, in which every moment contains the possibility that it will be interrupted (and thus of its being other). This is a moment constituted by a spacing, the spacing that holds potentiality and actuality apart. Now, however, it is no longer sustained by any form of positivity. It is a setup that is pressed on 
by the possibility of an interruption that can be called the caesura of allowing: in other words, an interruption that occasions, and, moreover, an occasioning delimited by justice. ${ }^{28}$ This need not give rise to an instrumentalization of politics. On the contrary; it is a philosophical thinking of revolution.

\section{BIBLIOGRAPHY}

AGAMBEN, Giorgio, Potentialities: Collected Essays in Philosophy, trans. Daniel Heller-Roazen (Stanford: Stanford University Press, 1999).

ARENDT, Hannah, On Violence (New York: Harcourt Brace Javanovich, 1970).

ARISTOTLE, Metaphysics: Books I-IX, trans. Hugh Tredennick (Cambridge, MA: Harvard University Press, 1989).

BENJAMIN, Andrew, "Recovering Holiness and the Place of Others: Notes on Vayikra", in: Parallax, Vol. 19, No. 4 (2013), pp.36-48.

BENJAMIN, Andrew, Virtue in Being: Towards an Ethics of the Unconditioned (Albany: SUNY Press, 2016).

BENJAMIN, Andrew, Working with Walter Benjamin: Recovering a Political Philosophy (Edinburgh: Edinburgh University Press, 2013).

BENJAMIN, Walter, "Notes to a Study on the Category of Justice", trans. Eric Jacobson, in: Eric Jacobson, Metaphysics of the Profane: The Political Theology of Walter Benjamin and Gershom Scholem (New York: Columbia University Press, 2003), pp.166-167.

BENJAMIN, Walter, “The Destructive Character", in: Selected Writings 2.2, 1931-1934, eds. Howard Eiland, Michael W. Jennings \& Gary Smith (Cambridge, MA: Harvard University Press, 1999), pp. 541-543.

BENJAMIN, Walter, The Origin of German Tragic Drama, trans. John Osborne (London: Verso, 1998).

BERKOVITS, Eliezer, Not in Heaven: The Nature and Function of Halakha (Jersey City: Ktav Publishing, 1983).

FENVES, Peter, The Messianic Reduction: Walter Benjamin and the Shape of Time (Stanford: Stanford University Press, 2010).

KANT, Immanuel, “Critique of Practical Reason”, in: Practical Philosophy, ed./ trans. Mary J. Gregor (Cambridge: Cambridge Univeristy Press, 1999), pp.133-272

KANT, Immanuel, “Metaphysics of Morals”, in Practical Philosophy, ed./trans. Mary J. Gregor (Cambridge: Cambridge Univeristy Press, 1999), pp.353-604.

KANT, Immanuel, “The Vienna Logic”, in: Lectures on Logic, ed./ trans. J. Michael Young (Cambridge: Cambridge University Press, 2001), pp.251-380.

KANT, Immanuel, Critique of the Power of Judgement, ed. Paul Guyer, trans. Paul Guyer \& Eric Matthews (Cambridge: Cambridge University Press, 2000). 
LESCH, C. H. T., “Against Politics: Walter Benjamin on Justice, Judaism, and the Possibility of Ethics”, in: American Political Science Review, 108, No. 1 (2014), pp.218-232.

MARX, Karl, “Theses on Feuerbach”, in: Selected Writings, ed. Lawrence H. Simon (Indianapolis: Hackett Publishing, 1994), pp. 98-102.

\section{NOTES}

1. This paper was initially given as a presentation at workshop organized by The Centre for Philosophy and Critical Thought at Goldsmiths, University of London, and the Walter Benjamin London Research Network, held at Goldsmiths on 28th April 2016. The other participants were Julia Ng and Massimiliano Tomba. The workshop was on Benjamin's text, "Notes to a Study on the Category of Justice". The text which was initially recorded in Gershom Scholem's Tagebücher dates from 1916. Rather than engage with every aspect of the "Notes", the priority in this presentation was to establish the ways in which connections and disassociations with Kant provided a framework within which to approach it. (Cf. Walter Benjamin, "Notes to a Study on the Category of Justice", trans. Eric Jacobson, in: Eric Jacobson, Metaphysics of the Profane: The Political Theology of Walter Benjamin and Gershom Scholem [New York: Columbia University Press, 2003], pp. 166-167.) All future references are to the text as cited below.

2. In addition to Jacobson's Metaphysics of the Profane, see: Peter Fenves, The Messianic Reduction: Walter Benjamin and the Shape of Time (Stanford: Stanford University Press, 2010). For an approach to Benjamin's text that emphasizes its link to Judaism as far more significant than Kant, see: C. H. T. Lesch, "Against Politics: Walter Benjamin on Justice, Judaism, and the Possibility of Ethics", in: American Political Science Review, 108, no. 1 (2014), pp. 218-232.

3. Benjamin, "Notes to a Study on the Category of Justice", p. 166.

4. In the Hebrew Bible, specifically Sefer Devarim 30:12, the place of the world is given an initially negative determination. The world's worldliness takes on the designation of "not in heaven". What is "not in heaven" is the place of law's actuality. That place is equally the location of the actualization of holiness. On the formulation from Sefer Devarim, see: Eliezer Berkovits, Not in Heaven: The Nature and Function of Halakha (Jersey City: Ktav Publishing, 1983). On the question of the place of holiness see: Andrew Benjamin, "Recovering Holiness and the Place of Others: Notes on Vayikra", in: Parallax, Vol. 19, No. 4 (2013), pp. 36-48.

5. A great deal of argumentation would need to be added at this precise point. In sum, however, the use of the term 'immanence' needs to be understood in relation to the distinction drawn by Kant both in the Critique of Pure Reason (1781) and in the Critique of Practical Reason (1788) between 'immanence' and 'transcendence'. In the latter Kant argues that: "the reality of the intelligible world is given to us, and indeed as determined from a practical perspective, and this determination, which for theoretical purposes would be transcendent (extravagant), is for practical purposes immanent". (Immanuel Kant, "Critique of Practical Reason", in: Practical Philosophy, ed./trans. Mary J. Gregor [Cambridge: Cambridge Univeristy Press, 1999], p. 224.)

6. Benjamin, "Notes to a Study on the Category of Justice", p.166 [Emphasis added]

7. Kant, "Critique of Practical Reason", p.241 [Emphasis added].

8. Immanuel Kant, "The Vienna Logic", in: Lectures on Logic, ed./ trans. J. Michael Young (Cambridge: Cambridge University Press, 2001), p. 259 [Emphasis added].

9. Kant, "Critique of Practical Reason", p.208 [Emphasis added].

10. Immanuel Kant, "Metaphysics of Morals", in: Practical Philosophy, ed./trans. Mary J. Gregor (Cambridge: Cambridge Univeristy Press, 1999), p.585. [Emphasis added].

11. Kant, "Critique of Practical Reason", p. 263. 
12. This passage from Aristotle is central to the argument developed here. Aristotle's claim does not privilege incapacity. On the contrary, the argument brings to the fore the problem of how a potentiality is actualized. In Aristotle this is a gradual process. It is precisely this possibility that is no longer available within modernity, once the latter is understood as a setting whose temporality has been naturalized such that it coincides with chronological time. The full passage

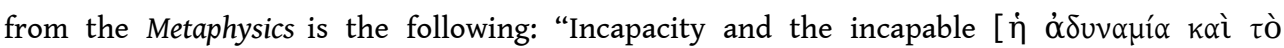

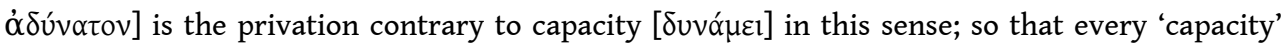

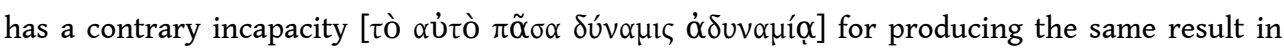
respect of the same subject." (Aristotle, Metaphysics: Books I-IX, trans. Hugh Tredennick [Cambridge, MA: Harvard University Press, 1989], p. 433.)

13. Immanuel Kant, Critique of the Power of Judgement, ed. Paul Guyer, trans. Paul Guyer \& Eric Matthews (Cambridge: Cambridge University Press, 2000), p. 141 [Emphasis added].

14. Benjamin, "Notes to a Study on the Category of Justice", p. 166.

15. Ibid.

16. Ibid [Translation altered].

17. Walter Benjamin, The Origin of German Tragic Drama, trans. John Osborne (London: Verso, 1998) p. 29-30. [Translation modified.]

18. Benjamin, "Notes to a Study on the Category of Justice", p. 166.

19. Ibid.

20. See Arendt's formulation of the distinction between power and violence. Hannah Arendt, On Violence (New York: Harcourt Brace Javanovich, 1970).

21. Benjamin, "Notes to a Study on the Category of Justice", p. 167.

22. Cf. Walter Benjamin, "The Destructive Character", in: Selected Writings 2.2, 1931-1934, eds. Howard Eiland, Michael W. Jennings \& Gary Smith (Cambridge, MA: Harvard University Press, 1999), pp. 541-543.

23. Benjamin, "Notes to a Study on the Category of Justice", p. 166.

24. Ibid.

25. Karl Marx, “Theses on Feuerbach", in: Selected Writings, ed. Lawrence H. Simon (Indianapolis : Hackett Publishing, 1994), p. 101.

26. I have discussed areas of possible affinity between Derrida's formulation of the 'unconditional' and Kant's thinking of the 'unconditioned' in my Virtue in Being. (Cf. Andrew Benjamin, Virtue in Being: Towards an Ethics of the Unconditioned [Albany: SUNY Press, 2016.])

27. Benjamin, "Notes to a Study on the Category of Justice", p. 167.

28. I have developed in much greater detail this conception of the caesura, which, it can be argued, forms a fundamental part of Walter Benjamin's thinking, in my Working with Walter Benjamin. (Cf. Andrew Benjamin, Working with Walter Benjamin: Recovering a Political Philosophy [Edinburgh: Edinburgh University Press, 2013.])

\section{ABSTRACTS}

There are clear affinities between the project that can be identified in Walter Benjamin's short text "Notes to a Study on the Category of Justice" and the philosophy of Kant. The aim of this paper is to show that despite possible affinities there is a fundamental divide concerning how the 'world' is thought. Both link justice to the world and yet the world as it appears in each instance 
is radically distinct. It is in terms of this distinction that the specific philosophical force of Benjamin's work emerges.

INDEX

Keywords: Benjamin Walter, Kant Immanuel, justice, world 